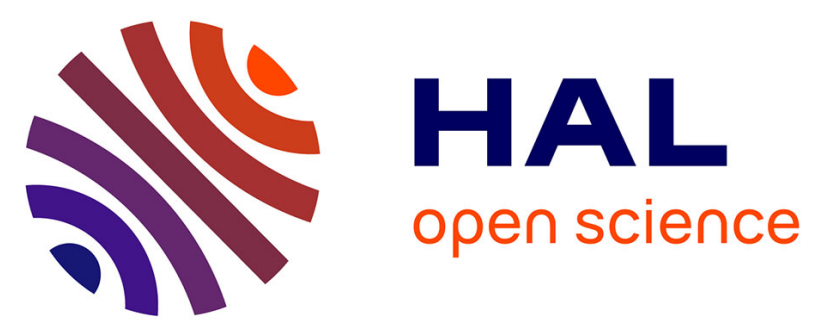

\title{
Occurrence of Bursaphelenchus mucronatus (Nematoda; Aphelenchoididae) in France and association with Monochamus galloprovincialis (Coleoptera: Cerambycidae)
}

Bruno Vincent, Fotini A. Koutroumpa, Valérie Altemayer, Géraldine

Roux-Morabito, Jeremy Gevar, Carine Martin, François Lieutier

\section{To cite this version:}

Bruno Vincent, Fotini A. Koutroumpa, Valérie Altemayer, Géraldine Roux-Morabito, Jeremy Gevar, et al.. Occurrence of Bursaphelenchus mucronatus (Nematoda; Aphelenchoididae) in France and association with Monochamus galloprovincialis (Coleoptera: Cerambycidae). Annals of Forest Science, 2008, 65 (1), pp.1-9. 10.1051/forest:2007083 . hal-00884154

\section{HAL Id: hal-00884154 https://hal.science/hal-00884154}

Submitted on 1 Jan 2008

HAL is a multi-disciplinary open access archive for the deposit and dissemination of scientific research documents, whether they are published or not. The documents may come from teaching and research institutions in France or abroad, or from public or private research centers.
L'archive ouverte pluridisciplinaire HAL, est destinée au dépôt et à la diffusion de documents scientifiques de niveau recherche, publiés ou non, émanant des établissements d'enseignement et de recherche français ou étrangers, des laboratoires publics ou privés. 


\title{
Occurrence of Bursaphelenchus mucronatus (Nematoda; Aphelenchoididae) in France and association with Monochamus galloprovincialis (Coleoptera: Cerambycidae)
}

\author{
Bruno Vincent, Fotini Koutroumpa, Valérie Altemayer, Géraldine RouX-Morabito, \\ Jeremy GEVAR, Carine MARTIN, François LIEUTIER*
}

Université d'Orléans, Laboratoire de Biologie des Ligneux et des Grandes Cultures, UPRES EA 1207, BP 6749, 45067, Orléans Cedex 2, France

(Received 3 September 2006; version revised 16 February 2007; accepted 17 April 2007)

\begin{abstract}
As a consequence of the recent introduction of the pine wood nematode Bursaphelenchus xylophilus in Portugal, nematodes of the genus Bursaphelenchus were looked for in various French pine forests, in trees attacked by Monochamus galloprovincialis, the vector insect of B. xylophilus, and in the insects themselves. Trap trees were felled in 12 localities distributed all over the country. Nematodes were extracted from transversal stem discs; insects emerging from the trap trees were studied. B. hellenicus, B. leoni, B. mucronatus and B. sexdentati were isolated, but not B. xylophilus. The presence of $B$. mucronatus and the absence of B. xylophilus were confirmed by molecular markers. $B$. mucronatus was isolated from several regions with an average prevalence of $19 \%$. The infestation of $M$. galloprovincialis by B. mucronatus reached $26.7 \%$. The wide distribution of $B$. mucronatus in France could have an effect on the extension of B. xylophilus in a case of an introduction.
\end{abstract}

pinewood nematodes / Bursaphelenchus spp. / vector insect / morphology / ITS-RFLP

Résumé - Présence de Bursaphelenchus mucronatus (Nematoda ; Aphelenchoididae) en France et association avec Monochamus galloprovincialis (Coleptera : Cerambycidae). Suite à la récente introduction du nématode du pin Bursaphelenchus xylophilus, au Portugal, les nématodes du genre Bursaphelenchus ont été recherchés dans diverses forêts de pins françaises, sur les arbres attaqués par Monochamus galloprovincialis, le vecteur de B. xylophilus, et sur les insectes eux-mêmes. Des arbres pièges ont été abattus dans 12 localités réparties sur le territoire national. Les nématodes ont été extraits de sections transversales de tronc, et les insectes émergeant des arbres pièges ont été étudié. $B$. hellenicus, $B$. leoni, $B$. mucronatus et $B$. sexdentati ont été isolés, mais pas $B$. xylophilus. La présence de $B$. mucronatus et l'absence de $B$. xylophilus ont été confirmées par des marqueurs moléculaires. B. mucronatus a été isolé de plusieurs régions avec une fréquence moyenne de $19 \%$. Le taux de contamination de M. galloprovincialis par B. mucronatus atteignait 26,7 \%. La vaste distribution de B. mucronatus en France pourrait avoir un effet sur la propagation de B. xylophilus dans le cas d'une introduction accidentelle.

nématodes du pin / Bursaphelenchus spp. / insecte vecteur / morphologie / ITS-RFLP

\section{INTRODUCTION}

Spread of non-indigenous species across their natural dispersal barriers by international travel and trade can lead to replacement of native species, causing disturbance of ecosystems $[16,17]$. Non-indigenous species are recognised as one of the leading global threats to native biodiversity and ecosystem function [42] and the pinewood nematode, Bursaphelenchus xylophilus $[26,39]$ is one of these species. It is a destructive pest of pines and is inferred to have been introduced early in the 1900s from North America into Japan [21] where it has been responsible for severe epidemic damage on Japanese black pine (Pinus thunbergii Palatore) and red pine (Pinus densiflora Siebold and Zuccarini) in central and south-western Japan for many years [24,41]. Pine trees in the north-western Pacific area (China, Korea, and Taiwan) have also been infested [22]. Its recent introduction in Portugal and

*Corresponding author: francois.lieutier@univ-orleans.fr its establishment in Pinus pinaster [25] represent a real threat for the European forests and raise the question of its possible introduction or extension in other European countries. The susceptibility of European pine species (Pinus sylvestris L., Pinus pinaster Ait and Pinus nigra Arnold) [12] has led B. xylophilus to be listed as a quarantine pest in Europe. The infection process of the nematode to trees requires an insect vector with larval stages occurring in dying trees. Beetles of the genus Monochamus (Coleoptera: Cerambycidae) are the most important vectors of the nematode worldwide [18] and Monochamus galloprovincialis Olivier is its vector in Portugal [38]. In France, B. xylophilus has never been observed but three species of Monochamus (M. galloprovincialis, M. sartor and $M$. sutor) are present, the most frequent being $M$. galloprovincialis on different pine species [4].

Monitoring of $B$. xylophilus is difficult because of the taxonomic confusion within the genus Bursaphelenchus [2, 24] due to very similar morphological characters in several 
Table I. Description of the localities investigated for studying the occurrence of Bursaphelenchus mucronatus. Last column indicates M. galloprovincialis occurrence from the 2003-2004 trap-campaign: (+) capture of M. galloprovincialis, (0) no capture of M. galloprovincialis.

\begin{tabular}{|c|c|c|c|c|c|c|c|c|}
\hline Locality & & Coordinates & $\begin{array}{l}\text { Altitude } \\
\text { (m) }\end{array}$ & Host & $\begin{array}{c}\text { Date } \\
\text { of felling }\end{array}$ & $\begin{array}{c}\text { Date } \\
\text { of collect }\end{array}$ & $\begin{array}{l}\text { Number } \\
\text { of logs }\end{array}$ & M. galloprovincialis \\
\hline 1 & Val de la Haye & $49^{\circ} 23^{\prime} \mathrm{N} / 0^{\circ} 59^{\prime} \mathrm{E}$ & 145 & P. sylvestris & 05/07/2004 & $07 / 10 / 2005$ & 20 & 0 \\
\hline 2 & Saint-Jean-aux-bois & $49^{\circ} 24^{\prime} \mathrm{N} / 2^{\circ} 52^{\prime} \mathrm{E}$ & 50 & P. strobus & $28 / 06 / 2004$ & $11 / 10 / 2005$ & 20 & + \\
\hline 3 & Sturzelbronn & $49^{\circ} 04^{\prime} \mathrm{N} / 7^{\circ} 34^{\prime} \mathrm{E}$ & 304 & P. sylvestris & $30 / 06 / 2004$ & $06 / 07 / 2005$ & 16 & + \\
\hline 4 & Cleebourg & $49^{\circ} 01^{\prime} \mathrm{N} / 7^{\circ} 53^{\prime} \mathrm{E}$ & 289 & P. sylvestris & $28 / 06 / 2004$ & 05/07/2005 & 15 & 0 \\
\hline 5 & Schirrhein & $48^{\circ} 50^{\prime} \mathrm{N} / 7^{\circ} 49^{\prime} \mathrm{E}$ & 158 & P. sylvestris & $21 / 06 / 2004$ & 05/07/2005 & 16 & 0 \\
\hline 6 & Lorris & $47^{\circ} 53^{\prime} \mathrm{N} / 2^{\circ} 24^{\prime} \mathrm{E}$ & 129 & P. sylvestris & $25 / 06 / 2004$ & $23 / 02 / 2005$ & 19 & + \\
\hline 7 & Savigny-les-Beaunes & $47^{\circ} 04^{\prime} \mathrm{N} / 4^{\circ} 48^{\prime} \mathrm{E}$ & 399 & P. nigra austriaca & 08/07/2004 & $07 / 07 / 2005$ & 17 & + \\
\hline 8 & St-Alban-des-Hurtières & $45^{\circ} 28^{\prime} \mathrm{N} / 6^{\circ} 17^{\prime} \mathrm{E}$ & 352 & P. sylvestris & $30 / 06 / 2004$ & $28 / 04 / 2005$ & 16 & 0 \\
\hline 9 & Vendays-Montalivet & $45^{\circ} 19^{\prime} \mathrm{N} / 1^{\circ} 09^{\prime} \mathrm{W}$ & 14 & P. pinaster & $26 / 08 / 2004$ & 05/06/2005 & 13 & + \\
\hline 10 & Bréau-et-Salagosse & $43^{\circ} 59^{\prime} \mathrm{N} / 3^{\circ} 32^{\prime} \mathrm{E}$ & 410 & P. nigra & $29 / 06 / 2004$ & $26 / 04 / 2005$ & 16 & + \\
\hline 11 & St-André-les-Alpes & $44^{\circ} 01^{\prime} \mathrm{N} / 6^{\circ} 29^{\prime} \mathrm{E}$ & 1100 & P. sylvestris & $28 / 06 / 2004$ & $27 / 04 / 2005$ & 15 & + \\
\hline 12 & Meyrargues & $43^{\circ} 37^{\prime} \mathrm{N} / 5^{\circ} 30^{\prime} \mathrm{E}$ & 321 & P. halepensis & $29 / 06 / 2004$ & $27 / 04 / 2005$ & 18 & + \\
\hline
\end{tabular}

species inhabiting pine wood. Techniques employing sex pheromones [31] as well as DNA analysis [6, 8, 13, 14, 30] have helped clarify the taxonomy of this group. PCR-RFLP of nuclear genes, especially ITS (Internal Transcribed Spacer) proved to produce appropriate markers for species identification, in particular to distinguish between $B$. mucronatus and $B$. xylophilus $[7,13,14]$. About 25 Bursaphelenchus species associated with conifers have been reported in Europe [5], among which Bursaphelenchus mucronatus [23] was the most abundant and present in many European countries [33]. In France, since its discovery in the Southwest on $P$. pinaster by Baujard in 1979 [3], B. mucronatus was never observed in any other pine species or locality. The European B. mucronatus has a low virulence in comparison to B. xylophilus [23] but displayed a moderate pathogenicity on pine seedlings during laboratory tests, although it never induced any visible damage on adult trees under natural conditions [34]. B. mucronatus displays similar morphological and biological characters than $B$. xylophilus [23] and occupies the same ecological niche in pine forest ecosystems. Moreover, the infection biology of the two species is also similar. Dispersal fourth-stage juveniles of both species are transported from one host tree to another by beetles of the genus Monochamus [18, 23,24].

In general, host species can harbour several species of parasites [28]. Nevertheless, because a host is a finite resource, parasites that share the same host species can adversely affect each other's densities through interspecific competition [10]. Thus, when B. xylophilus is introduced in a new area where $B$. mucronatus is already present, it must share resources, such as food and vector species, with $B$. mucronatus. Consequently, studying the distribution of $B$. mucronatus in the absence of B. xylophilus could give useful information on the modalities of a possible dissemination of this latter in case it would be introduced.

The aim of this study was to determine the infestation level by B. mucronatus of different pine species in France, and its phoretic relationships with $M$. galloprovincialis. The study focused mainly on Pinus sylvestris, Pinus halepensis, Pinus pinaster and Pinus nigra, because these species are representative of the French pine forests.

\section{MATERIALS AND METHODS}

\subsection{Nematode sampling and extraction}

In summer 2004, four healthy pine trees were felt in each of twelve localities in France during the flight period of M. galloprovincialis adults, to be used as trap trees for the beetle. As much as possible but also depending on practical possibilities in the field, these localities were chosen so that they are representative of the different types of coniferous forests in France. The choice also resulted from a preliminary sampling of Monochamus galloprovincialis in 40 sites, and nematode sampling was done mainly in localities where $M$. galloprovincialis had been previously found. The characteristics and locations of the localities are presented in Table I and Figure 1. Entire trees were left in the field until April 2005. In May, four to five logs (about $45 \mathrm{~cm}$ long and $9 \mathrm{~cm}$ mid-diameter) were cut off mainly from the top of each tree (201 logs in total). Each log was checked for the presence of $M$. galloprovincialis (larval and adult feeding). A $1 \mathrm{~cm}$ thick stem disc was taken from each log to further extract nematodes, and the logs were then placed individually in $70 \mathrm{~cm}$ diameter $\times 70 \mathrm{~cm}$ deep plastic containers covered with tulle. The containers were placed at $20^{\circ} \mathrm{C}$ and checked two times a week from May to September until emergence of M. galloprovincialis (Tab. II). The number of emergence holes was counted. Beetles were dissected and crushed in sterilised water and then kept in water at $20-24{ }^{\circ} \mathrm{C}$ during $24 \mathrm{~h}$ for the nematode juveniles to gather in water. The discs taken from the logs were kept in a plastic bag at room temperature during one to three months, until nematode extraction. Nematodes were extracted from the discs during $48 \mathrm{~h}$ with a modified Baermann funnel technique [27], involving immersion of pieces of wood in water. Nematodes were collected from the closed bottom of a funnel, after their migration out of the wood. 


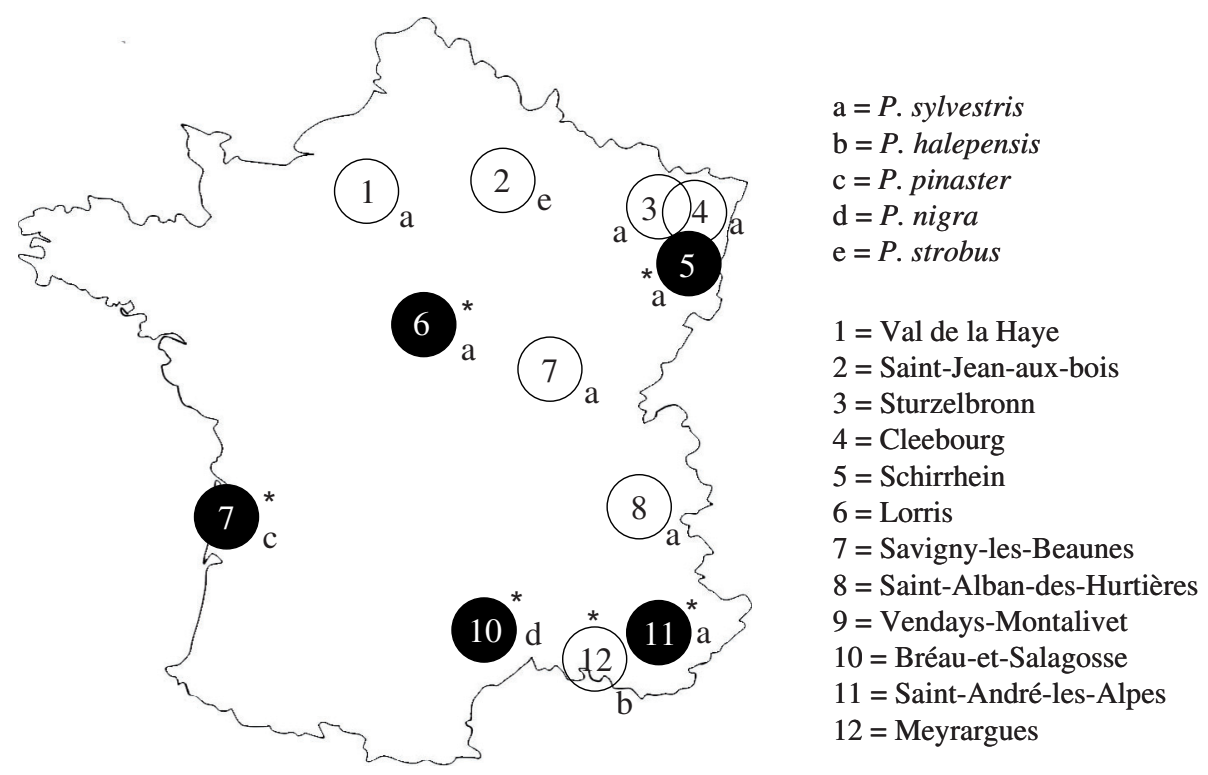

Figure 1. Map of the sampling sites (see Tab. I). Black disks = areas where Bursaphelenchus mucronatus was present; white disks = areas where Bursaphelenchus mucronatus was not found. * Localities where Monochamus galloprovincialis emergence holes were found.

Table II. Contingency table: occurrence of Bursaphelenchus mucronatus in relation to the presence of Monochamus galloprovincialis grub holes in all the localities.

\begin{tabular}{lcc}
\hline & $\begin{array}{c}\text { Number of trees with } \\
\text { M. galloprovincialis emergence holes }\end{array}$ & $\begin{array}{c}\text { Number of trees without } \\
\text { M. galloprovincialis emergence holes }\end{array}$ \\
\hline B. mucronatus present & 8 & 1 \\
B. mucronatus absent & 4 & 35 \\
\hline Total & 12 & 36 \\
\hline c2 $=24.114 ; p=1.08 .10^{-5}<<0.05$ (significant).
\end{tabular}

\subsection{Nematode preparation and morphological observations}

Nematodes present in water were transferred with a pipette and a lash, to a glass slide, under a stereomicroscope. Some Bursaphelenchus specimens were fixed in FA 4:1 hot solution (40\% formaldehyde, glacial acid acetic), using the glycerol-ethanol method [35] then fixed in anhydrous glycerin for identification. Observations were made from alive and fixed adult specimens using a digital biological microscope (Model DMWB1-223) and Motic Images Plus 2.0 software. Bursaphelenchus identification was based on morphological characters, particularly vulval flap, shape of spicules and female tail [5, 33, 44], and measurements. Measurements concerned body length $(=\mathrm{L}), \mathrm{L} /$ maximum body width $(=\mathrm{a})$, L/oesophageal length $(=\mathrm{b}), \mathrm{L} /$ tail length $(=\mathrm{c})$, stylet length, (distance from head end to vulva/L) $\times 100(=\mathrm{V})$, spicules length $(=\mathrm{S})$. Each individual was measured using Image $\mathbf{J}$ software calibrated with a stage micrometer.

Nematode species extracted from pines, with morphometric characteristics similar to B. xylophilus (belonging to the B. xylophilusgroup [33]), and juveniles $\mathrm{J}_{\text {IV }}$ extracted from insects, were identified by molecular methods: 15 individuals/locality extracted from pines were analysed for Schirrhein, Lorris, Bréau-et-Salagosse and 5 for Vendays-Montalivet and Saint-André-les-Alpes; 10 individuals/insect were analysed.

\subsection{Molecular methods}

Nematodes were prepared according to the single worm PCR procedure modified by Castagnone et al. [8]. Single nematodes were transferred to a dry thin walled PCR tube, covered with $15 \mu \mathrm{L}$ lysis buffer (1X Buffer PCR, $6 \mu \mathrm{g} . \mu \mathrm{L}^{-1}$ proteinase $\mathrm{K}$ ). Tubes were put at $-80^{\circ} \mathrm{C}$ for $60 \mathrm{~min}$ and immediately transferred to $60{ }^{\circ} \mathrm{C}$ for $60 \mathrm{~min}$ and then $95{ }^{\circ} \mathrm{C}$ for $15 \mathrm{~min}$ in the thermocycler.

Extracted nematode DNA was compared with ITS-RFLP markers (Internal Transcribed Spacer-Restriction Fragment Length Polymorphism). The ITS regions of rDNA were amplified using primers F194 (5'- CGTAACAAGGTAGCTGTAG-3') and P5368 (5'-TTTCACTCGCCGGTTACTAAGG-3') as described by Ferris et al. [11] and Vrain [43], respectively. All polymerase chain reactions were performed in a final volume of $25 \mu \mathrm{L}$ using $10 \mathrm{ng} / \mu \mathrm{L}$ of template DNA, $1 \mu \mathrm{M}$ of each primer, $0.2 \mu \mathrm{M}$ of dNTPs, $2 \mathrm{U}$ of Taq DNA polymerase, $1 \times$ Reaction Buffer and $1.25 \mathrm{mM}$ of $\mathrm{MgCl} 2$. The reaction consisted of one denaturation step at $94{ }^{\circ} \mathrm{C}$ for $1 \mathrm{~min}, 35$ cycles at $94{ }^{\circ} \mathrm{C}$ for $1 \mathrm{~min}, 51{ }^{\circ} \mathrm{C}$ for $1 \mathrm{~min}$, and $72{ }^{\circ} \mathrm{C}$ for $2 \mathrm{~min}$, followed by a final extension step at $72{ }^{\circ} \mathrm{C}$ for $5 \mathrm{~min}$. Digestion of the amplified ITS region was performed with HaeIII, MspI and HinfI endonucleases, using an aliquot of $4 \mu \mathrm{L}$ of the PCR product and $10 \mathrm{U}$ of each enzyme. Patterns observed on $2 \%$ agarose gel after the digestion by endonucleases were compared to Bursaphelenchus species 


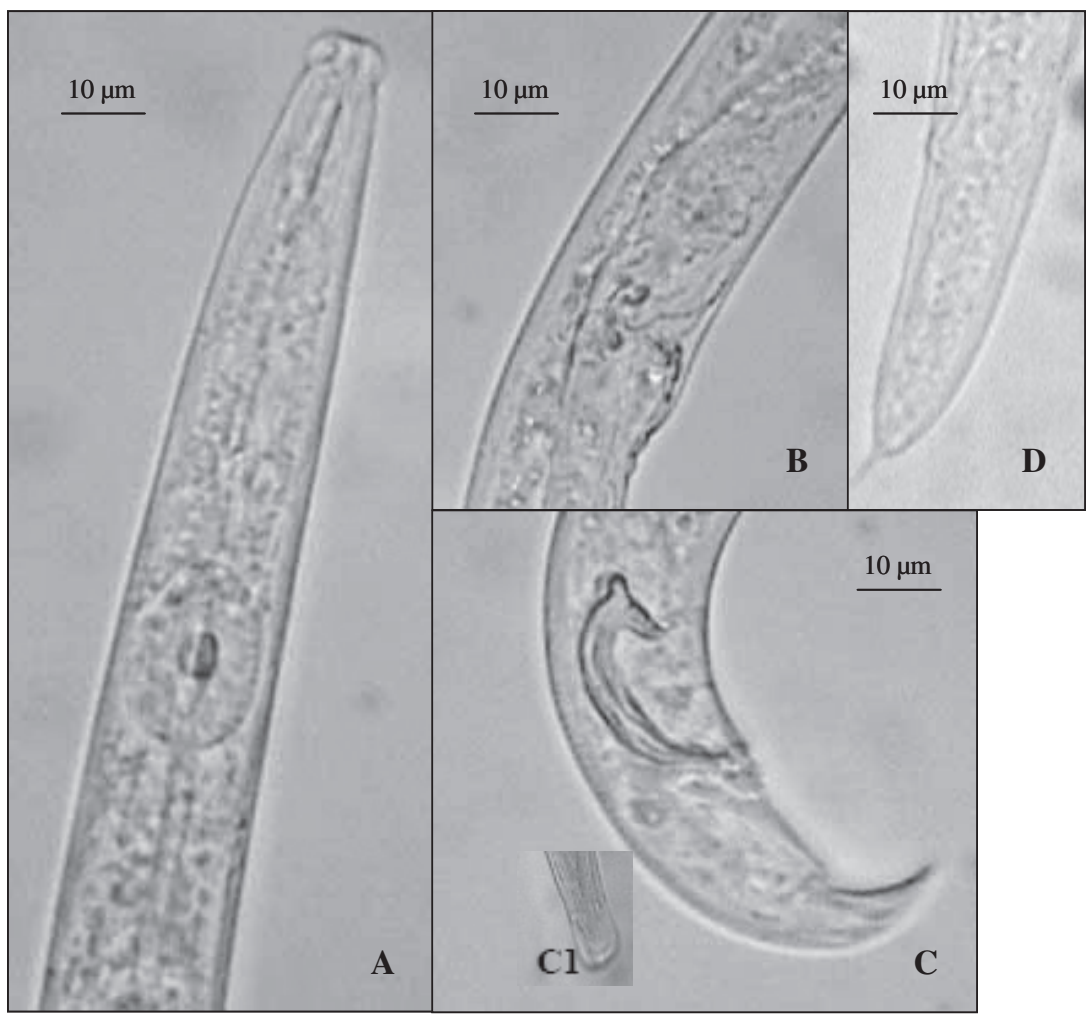

Figure 2. Light micrographs of Bursaphelenchus mucronatus. A: anterior region; B: vulval region; C: male tail, with bursa in inset (C1); D: female tail.

reference patterns [7]. Fragment sizes were estimated by comparison with a DNA size marker (Smart Ladder, Eurogentec).

\subsection{Statistics}

The percentage of trees contaminated by $B$. mucronatus, in the localities where this nematode was present, as well as the percentage of infested insects, were tested with a $\chi^{2}$ test. The association between the presence of $M$. galloprovincialis emergence holes and the presence of $B$. mucronatus was assessed in a contingency table using a Fisher exact test throughout the trees analysed. All results were evaluated using the SPSS statistical software package (SPSS, Chicago, IL, USA). For each morphological measurement, the mean was expressed with its standard deviation. All statistical tests were considered significant when $P \leq 0.05$.

\section{RESULTS}

\subsection{Identification of $B$. mucronatus populations}

B. xylophilus-group individuals observed in our samples (Fig. 2, Tabs. III and IV) corresponded to the description of B. mucronatus, done by Mamiya and Enda [23]. Our male specimens showed the typical, strongly curved, cucullus bearing spicules of the xylophilus-group [5,33]. The females had a vulva postmedian with a proeminent vulvar flap. The tail was conoid with a mucro.
Amplification of ITS regions of studied samples produced a single DNA fragment of $950 \mathrm{bp}$. The same $950 \mathrm{bp}$ amplicon was also obtained with $B$. mucronatus, $B$. xylophilus and $B$. eggersi [7]. Subsequent analysis of ITS regions with HaeIII, MspI and HinfI endonucleases produced characteristic patterns for all individuals studied (Fig. 3) similar to those obtained with the European type of B. mucronatus [7].

\subsection{Occurrence of B. mucronatus}

M. galloprovincialis emergence holes were observed from the collected logs in six localities (Fig. 1): Schirrhein $(P$. sylvestris), Lorris ( $P$. sylvestris), Vendays-Montalivet $(P$. pinaster), Bréau-et-Salagosse ( $P$. nigra), Saint-André-lesAlpes (P. sylvestris) and Meyrargues (P. halepensis). B. тиcronatus was detected from logs in five localities, all where $M$. galloprovincialis emergence holes had been observed (Fig. 1). Half of trees was contaminated by B. mucronatus in Schirrhein, Lorris and Bréau-et-Salagosse, and a quarter in Vendays-Montalivet and Saint-André-les-Alpes, without significant difference among localities $\left(\chi^{2}=0.8 ; p=0.371\right)$ and corresponding to an averaged prevalence of $40 \%$. The number of individuals extracted from logs was always low: $80 \mathrm{~g}^{-1}$ of wood at Lorris, $30 \mathrm{~g}^{-1}$ at Schirrhein, $45 \mathrm{~g}^{-1}$ at Bréau-etSalagosse, less than $10 \mathrm{~g}^{-1}$ at Vendays-Montalivet and SaintAndré-les-Alpes. 
Table III. Measurements on males of Bursaphelenchus spp. isolated in France, compared to Allotypes. All measurements are in $\mu \mathrm{m}$ (mean \pm standard deviation, with range in parenthesis).

\begin{tabular}{|c|c|c|c|c|c|c|c|}
\hline \multirow{2}{*}{$\begin{array}{l}\text { Species } \\
\text { Locality or Reference }\end{array}$} & \multirow[b]{2}{*}{$n$} & \multicolumn{6}{|c|}{ Morphometric characters } \\
\hline & & $L$ & $a$ & $b$ & $c$ & Stylet & $S$ \\
\hline \multicolumn{8}{|l|}{ B. mucronatus } \\
\hline Schirrhein & 30 & $\begin{array}{l}802 \pm 14.5 \\
(644-994)\end{array}$ & $\begin{array}{c}48.3 \pm 0.9 \\
(39.8-57.0)\end{array}$ & $\begin{array}{l}10.2 \pm 0.2 \\
(8.8-12.6)\end{array}$ & $\begin{array}{c}22.4 \pm 0.4 \\
(17.8-27.6)\end{array}$ & $\begin{array}{c}15.5 \pm 0.3 \\
(12.5-18.0)\end{array}$ & $\begin{array}{l}25.3 \pm 0.4 \\
(21.4-31.8)\end{array}$ \\
\hline Lorris & 53 & $\begin{array}{l}810 \pm 15.7 \\
(671-1086)\end{array}$ & $\begin{array}{c}43.1 \pm 0.8 \\
(32.0-55.9)\end{array}$ & $\begin{array}{l}10.9 \pm 0.2 \\
(9.0-13.8)\end{array}$ & $\begin{array}{c}22.0 \pm 0.4 \\
(13.4-25.6)\end{array}$ & $\begin{array}{c}15.2 \pm 0.3 \\
(13.0-17.9)\end{array}$ & $\begin{array}{c}26.8 \pm 0.4 \\
(21.6-31.3)\end{array}$ \\
\hline St-André-les-Alpes & 5 & $\begin{array}{l}763 \pm 30.2 \\
(676-845)\end{array}$ & $\begin{array}{c}46.5 \pm 2.3 \\
(41.1-54.8)\end{array}$ & $\begin{array}{l}10.8 \pm 0.4 \\
(9.6-12.0)\end{array}$ & $\begin{array}{l}23.0 \pm 0.6 \\
(21.5-24.6)\end{array}$ & $\begin{array}{c}13.3 \pm 0.4 \\
(12.5-14.2)\end{array}$ & $\begin{array}{c}24.7 \pm 0.6 \\
(22.5-26.0)\end{array}$ \\
\hline Vendays-Montalivet & 2 & $\begin{array}{l}798 \pm 82.7 \\
(715-881)\end{array}$ & $\begin{array}{c}43.5 \pm 1.3 \\
(42.1-44.8)\end{array}$ & $\begin{array}{l}9.1 \pm 0.9 \\
(8.2-9.9)\end{array}$ & $\begin{array}{c}21.2 \pm 1.4 \\
(19.8-22.7)\end{array}$ & $\begin{array}{c}14.8 \pm 1.4 \\
(13.5-16.2)\end{array}$ & $\begin{array}{c}29.5 \pm 0.2 \\
(29.2-29.8)\end{array}$ \\
\hline Bréau-et-Salagosse & 28 & $\begin{array}{l}840 \pm 15.8 \\
(698-1000)\end{array}$ & $\begin{array}{c}46.5 \pm 0.8 \\
(38.4-58.0)\end{array}$ & $\begin{array}{l}12.2 \pm 0.3 \\
(9.0-15.4)\end{array}$ & $\begin{array}{c}23.9 \pm 0.5 \\
(18.3-28.0)\end{array}$ & $\begin{array}{c}15.3 \pm 0.3 \\
(12.2-17.5)\end{array}$ & $\begin{array}{c}26.8 \pm 0.4 \\
(23.3-31.7)\end{array}$ \\
\hline $\begin{array}{l}\text { B. mucronatus - Allotype } \\
\text { (Mamiya \& Enda, 1979) }\end{array}$ & - & 830 & 46.3 & 12.0 & 30.3 & 15.0 & 26.5 \\
\hline $\begin{array}{l}\text { B. lignicolus - France (= B. mucronatus) } \\
\text { (Baujard et al., 1979) }\end{array}$ & - & 692 & 42.2 & 10.4 & 25.8 & 13.0 & 25.3 \\
\hline $\begin{array}{l}\text { B. mucronatus (min-max) } \\
\text { (Braasch, 2001) }\end{array}$ & - & $(480-1103)$ & $(25-59)$ & - & $(15-36)$ & $(12-18)$ & $(16-33)$ \\
\hline \multicolumn{8}{|l|}{ B. sexdentati Syn. : B. naujaci Baujard, 1980} \\
\hline Lorris & 8 & $\begin{array}{l}866 \pm 18.7 \\
(784-915)\end{array}$ & $\begin{array}{c}41.7 \pm 0.8 \\
(39.6-45.1)\end{array}$ & $\begin{array}{c}14.4 \pm 0.4 \\
(12.2-16.1)\end{array}$ & $\begin{array}{c}27.4 \pm 3.2 \\
(22.7-49.3)\end{array}$ & $\begin{array}{c}17.0 \pm 0.4 \\
(14.8-18.0)\end{array}$ & $\begin{array}{l}14.9 \pm 0.3 \\
(13.6-15.7)\end{array}$ \\
\hline St-André-les-Alpes & 7 & $\begin{array}{l}776 \pm 18.3 \\
(720-862)\end{array}$ & $\begin{array}{c}45.0 \pm 1.6 \\
(39.2-51.6)\end{array}$ & $\begin{array}{c}12.5 \pm 0.3 \\
(11.3-13.9)\end{array}$ & $\begin{array}{c}22.1 \pm 0.8 \\
(18.9-24.1)\end{array}$ & $\begin{array}{c}13.4 \pm 0.3 \\
(12.6-14.9)\end{array}$ & $\begin{array}{c}14.1 \pm 0.3 \\
(13.1-14.9)\end{array}$ \\
\hline Vendays-Montalivet & 19 & $\begin{array}{l}1059 \pm 26.9 \\
(856-1234)\end{array}$ & $\begin{array}{c}48.1 \pm 1.3 \\
(35.9-59.9)\end{array}$ & $\begin{array}{c}14.3 \pm 0.4 \\
(11.9-18.3)\end{array}$ & $\begin{array}{c}26.4 \pm 1.0 \\
(20.6-35.7)\end{array}$ & $\begin{array}{c}16.1 \pm 0.3 \\
(13.4-18.0)\end{array}$ & $\begin{array}{c}15.5 \pm 0.5 \\
(12.2-20.1)\end{array}$ \\
\hline $\begin{array}{l}\text { B. sexdentati - Allotype } \\
\text { (Rühm, 1960) }\end{array}$ & - & 924 & 41.7 & 13.6 & 25.4 & 18.0 & 20.5 \\
\hline $\begin{array}{l}\text { B. naujaci-France } \\
\text { (Baujard, 1980) }\end{array}$ & - & 890 & 42.0 & 13.0 & 24.0 & 15.0 & 17.0 \\
\hline $\begin{array}{l}\text { B. sexdentati (min-max) } \\
\text { (Braasch, 2001) }\end{array}$ & - & $(541-1154)$ & $(36-59)$ & - & $(25-36)$ & $(12-18)$ & $(13-22)$ \\
\hline $\begin{array}{l}\text { B. naujaci }(\min -\max ) \\
\text { (Braasch, 2001) }\end{array}$ & - & $(560-1200)$ & $(33-63)$ & - & $(17-30)$ & $(13-18)$ & $(13-22)$ \\
\hline \multicolumn{8}{|l|}{ B. leoni } \\
\hline Lorris & 1 & 712 & 36.7 & 10.2 & 23.3 & 13.7 & 15.9 \\
\hline $\begin{array}{l}\text { B. leoni-Allotype - France } \\
\text { (Baujard, 1980) }\end{array}$ & - & 760 & 47 & 10 & 25 & 13 & 16 \\
\hline $\begin{array}{l}\text { B. leoni }(\min -\max ) \\
\text { (Braasch, 2001) }\end{array}$ & - & $(510-1060)$ & $(26-56)$ & - & $(16-30)$ & $(12-17)$ & $(10-21)$ \\
\hline \multicolumn{8}{|l|}{ B. hellenicus } \\
\hline Bréau-et-Salagosse & 16 & $\begin{array}{l}695 \pm 17.4 \\
(565-798)\end{array}$ & $\begin{array}{c}30.5 \pm 0.7 \\
(26.0-34.2)\end{array}$ & $\begin{array}{l}8.7 \pm 0.2 \\
(7.4-9.9)\end{array}$ & $\begin{array}{c}21.4 \pm 0.6 \\
(18.6-27.1)\end{array}$ & $\begin{array}{c}14.7 \pm 0.2 \\
(13.5-17.3)\end{array}$ & $\begin{array}{l}14.9 \pm 0.3 \\
(12.8-6.7)\end{array}$ \\
\hline $\begin{array}{l}\text { B. hellenicus - Allotype } \\
\text { (Skarmoutsos et al., 1998) }\end{array}$ & - & 770 & 33.0 & 8.3 & 21.0 & 16.0 & 15.0 \\
\hline $\begin{array}{l}\text { B. hellenicus (min-max) } \\
\text { (Braasch, 2001) }\end{array}$ & - & $(640-820)$ & $(22-38)$ & - & $(19-30)$ & $(13-17)$ & $(12-18)$ \\
\hline
\end{tabular}

$n=$ Number of examined specimens; $L=$ body length; $a=\mathrm{L} /$ maximum body width; $b=\mathrm{L} /$ oesophageal length; $c=\mathrm{L} /$ tail length; stylet length;

$V=($ distance from head end to vulva/L) $\times 100 ; S=$ spicules length. 
Table IV. Measurements on females of various Bursaphelenchus spp. isolated in France, compared to Allotypes. All measurements are in $\mu$ m (mean \pm standard deviation, with range in parenthesis).

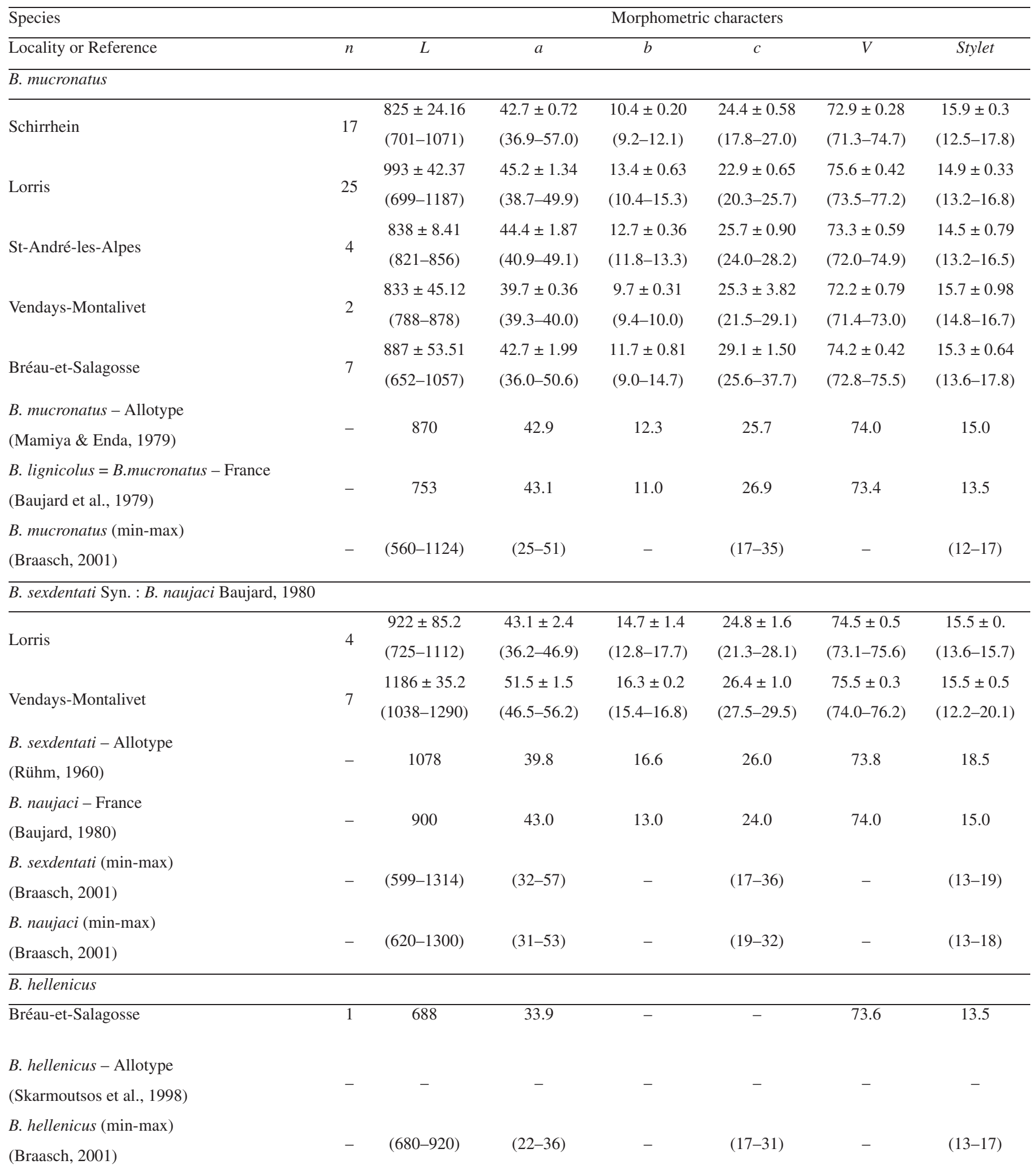

$n=$ Number of examined specimens; $L=$ body length; $a=\mathrm{L} /$ maximum body width; $b=\mathrm{L} /$ oesophageal length; $c=\mathrm{L} /$ tail length; stylet length; $V=($ distance from head end to vulva/L) $\times 100 ; S=$ spicules length. 


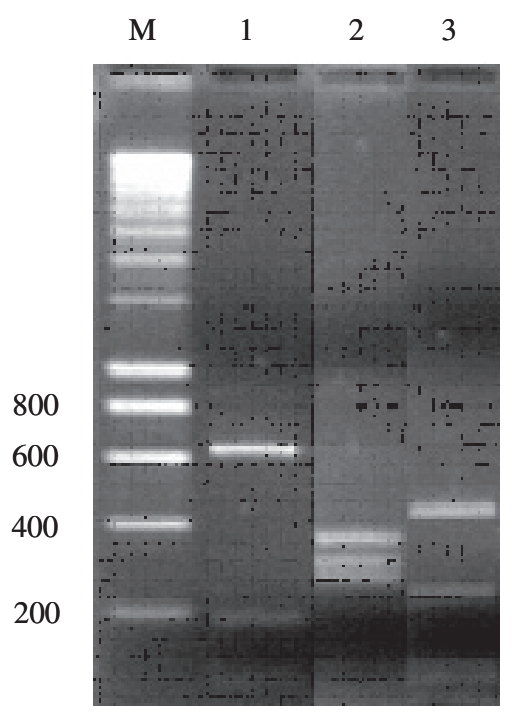

Figure 3. ITS-RFLP patterns of a Bursaphelenchus mucronatus individual from Bréau-et-Salagosse (France). Restriction fragments were obtained by digestion of the amplified rDNA fragment with Hae III (1), Msp I (2), Hinf I (3). M: DNA marker.

In Bréau-et-Salagosse and Lorris, the emerging insects were infested with B. mucronatus at a rate of $12.5 \%$ and $26.7 \%$, respectively (difference not significant: $\chi^{2}=0.672$; $p=0.41$ ). No nematode was extracted from the 89 insects emerged from P. halepensis at Meyrargues and from the 4 insects at Vendays-Montalivet. Unfortunately at Schirrhein and Saint-André-les-Alpes, the insects had already emerged when the logs were brought to the lab and thus no M. galloprovincialis could be collected. Considering all localities, $66 \%$ of trees with M. galloprovincialis emergence holes and 3\% of trees without $M$. galloprovincialis emergence holes were infested by B. mucronatus. The occurrence of B. mucronatus was significantly associated with the presence of $M$. galloprovincialis emergence holes on trees $\left(\chi^{2}=24.114 ; p<<0.05\right)$ (Tab. II).

\subsection{Occurrence of other Bursaphelenchus species}

Besides B. mucronatus, other Bursaphelenchus species were collected sporadically and isolated from logs. Because of the low number of individuals, they were described by using morphological characters (Fig. 4) which make them resembling to $B$. leoni, B. sexdentati and B. hellenicus and were concordant to the previous species description $[2,32,37]$. Morphometrical characters were also used and were concordant with the allotypes and fitted within the limits found by Braasch [5] (Tabs. III and IV).

\section{DISCUSSION}

Most individuals found in our localities resembled morphologically to nematodes of the B. xylophilus-group [33]. However, the use of the ITS-molecular marker demonstrated un-

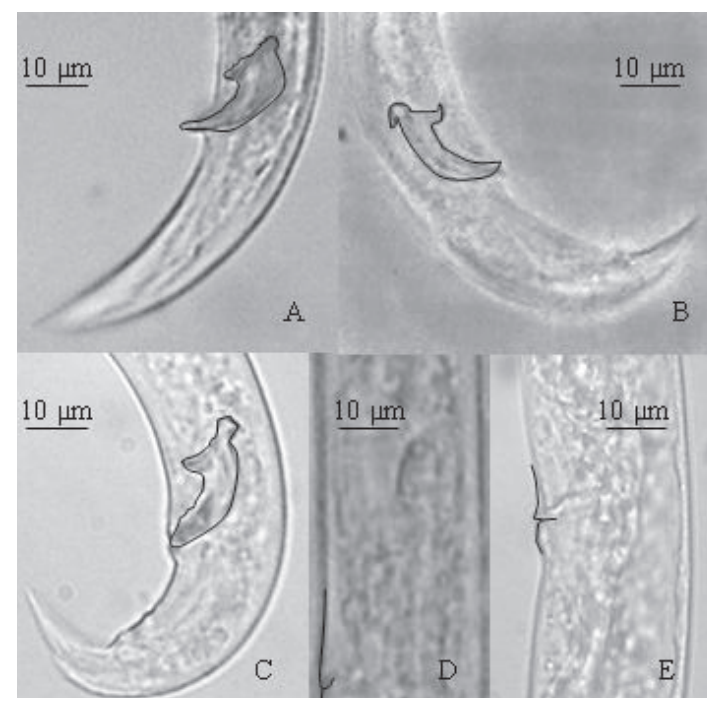

Figure 4. Light micrographs of the 3 other Bursaphelenchus species. A: B. hellenicus male tail; B: B. leoni male tail; C: B. sexdentati male tail; D: B. sexdentati vulval region; E: $B$. hellenicus vulval region. Morphological characters as spicules and vulvar lips were accentuated by black lines.

equivocally that all these specimens belonged to the species $B$. mucronatus.

Therefore our results support the hypothesis that the presence of B. xylophilus in France is very unlikely.

The direct isolation of B. mucronatus from individuals of $M$. galloprovincialis and the existence of a significant association in logs between $M$. galloprovincialis emergence holes and B. mucronatus positive wood samples demonstrate that these species are associated such an association has already been reported several times [33].

Our investigations on fallen trees showed the occurrence of $B$. mucronatus in five among twelve localities where its insect vector $M$. galloprovincialis had been recorded. B. тиcronatus has already been reported from south-western France in $P$. pinaster [3], where it was first misidentified as $B$. xylophilus [9]. B. тисronatus found in our samples displayed similar size (Tab. III) and morphology (mucronate tail) as $B$. mисronatus specimens found in 1979 in south-western France in $P$. pinaster. B. mucronatus thus seems to be widely distributed in France. Nineteen percent of the analysed trees contained B. mucronatus. The nematode was found on three pine species: P. nigra, $P$. pinaster and $P$. sylvestris. It has already been identified in these species in other European countries [29,33]: in P. nigra and P. sylvestris in Austria and Spain, in $P$. pinaster in Portugal and Italy and in P. sylvestris in Norway, Sweden, Finland, Poland, Germany and Switzerland.

Although there was no significant difference between localities in the prevalence of $B$. mucronatus, there were contrasted results regarding the abundance of $B$. mucronatus individuals per gram of wood. Factors affecting the number of nematodes transmitted to trees by beetles can certainly interfere, for example through initial nematode load and longevity of insect vector, which can themselves depend on humidity 
and fungal flora in the beetle galleries, as shown for $B$. $x y$ lophilus $[19,20,36,40]$. The local abundance of the main vector also certainly plays a role in the intensity of infestation by $B$. mucronatus since, when considering the localities where $B$. mucronatus was found in our results, the number of wood samples containing B. mucronatus was directly related to the number of $M$. galloprovincialis emergence holes. However, other factors are also certainly involved, such as differences in site locations and host trees, and possibly associated fungi. For $B$. xylophilus, intense blue-stain on the pupal chamber walls of $M$. alternatus increased the number of pinewood nematodes [20].

Morphometric characters allowed suggesting the existence of populations of B. mucronatus, B. sexdentati, B. leoni and $B$. hellenicus. However within each species, it was not possible, with these parameters, to separate the populations geographically or according to their pine host. Only B. mucronatus was found in association with $M$. galloprovincialis. The others species were found directly on pines; these three species were known to be associated with Scolytinae such as Ips sexdentatus, Tomicus piniperdae, Dryocoetes autographus and Hylurgops palliatus [5,7] which are common in French pine forests [1]. Some sampling trees were probably attacked by Scolitydae contaminated with nematodes which then migrated inside the tree. B. sexdentati (syn. B. naujaci) and B. leoni were already found in France (Les Landes) on $P$. pinaster [2] and correspond to the measurements of our specimens.

In conclusion, the wide distribution of $B$. mucronatus in France is interesting under the hypothesis that its presence in M. galloprovincialis and in pines can, as a possible result of competition, lower the initial load of B. xylophilus in the insects, and thus impede the geographical extension of this latter species. An inhibitory effect of B. mucronatus on the number of B. xylophilus in its vector has already been shown for Monochamus alternatus [15]. It would be interesting to test the interaction between B. mucronatus (French samples) and B. xylophilus (Portuguese samples) in the transmission process by M. galloprovincialis to trees. Interestingly in Portugal, B. mucronatus does not seem to occur in the quarantine area where damage is caused by B. xylophilus [38]. No B. mucronatus was recorded on $P$. halepensis at Meyrargues despite the high number of $M$. galloprovincialis in this locality. Furthermore, no B. mucronatus was found either in the beetles collected in this area. This observation is in agreement with the fact that $B$. mucronatus seems to be rare in the Mediterranean area [5], although its main vector, $M$. galloprovincialis, is abundant. This empty niche and locally high number of potential vectors could make Meyrargues a locality where the establishment of B. xylophilus would be facilitated.

Acknowledgements: This work was supported by a grant from the Ministère de l'Agriculture, de l'Alimentation, de la Pêche et des Affaires Rurales (MAPAR) and the Conseil Régional de la Région Centre. We wish to thanks F.X. Saintonge and L.M. Nageleisen (Département de la Santé des Forêts, MAPAR) for their advises when drawing up the protocole, and P. Levannier, D. Mure, H. Schmuck, R. Durand, F. Dorfer, J. Garcia, B. Huttinger, J.P. Henry, J.P. Coste, C. Rullière, L. Micas, J. Hintzy for their help in sampling. We are also grateful to P. Castagnone and C. Castagnone from the Institut National de
Recherche Agronomique, Sophia-Antipolis, France, for their advises in molecular biology.

\section{REFERENCES}

[1] Balachowsky A., Faune de France, Coléoptères Scolytides, Librairie de la Faculté des Sciences, Paris, 320 p.

[2] Baujard P., Trois nouvelles espèces de Bursaphelenchus (Nematoda: Tylenchida) et remarques sur le genre, Rev. Nématol. 3 (1980) 167-177.

[3] Baujard P., Boulbria A., Ham R., Laumond C., Scotto La Massese C., Premières données sur la nématofaune associée aux dépérissements du pin maritime dans l'Ouest de la France, Ann. Sci. For. 36 (1979) 331-339.

[4] Bense A., Longhorn beetles: illustrated key to the Cerambycidae and Vesperidae of Europe, Weikersheim, Germany, Margraf, 1995, $512 \mathrm{p}$.

[5] Braasch H., Bursaphelenchus species in conifers in Europe: distribution and morphological relationships, Bull. OEPP 31 (2001) 127142.

[6] Braasch H., Burgermeister W., Pastrik K.H., Differentiation of three Bursaphelenchus species by means of RAPD-PCR, Nachrichtenbl. Deut. Pflanzenschutzd. 47 (1995) 310-314.

[7] Braasch H., Metge K., Burgermeister W., BursaphelenchusArten (Nematoda, Parasitaphelenchidae) in Nadelgehölzen in Deutschland und ihre ITS-RFLP-Muster, Nachrichtenbl. Deut. Pflanzenschutzd. 51 (1999) 312-320.

[8] Castagnone C., Abad P., Castagnone-Sereno P., Short communication: Satellite DNA-based species-specific identification of single individuals of the pinewood nematode Bursaphelenchus xylophilus (Nematoda: Aphelenchoididae), Eur. J. Plant Pathol. 112 (2005) 191-193.

[9] De Guiran G., Boulbria A., Le nématode des pins. Caractéristiques de la souche française et risque d'introduction et d'extension de Bursaphelenchus xylophilus en Europe, Bull. OEPP 16 (1986) 445452.

[10] Dobson A., The population dynamics of competition between parasites, Parasitology 91 (1985) 317-347.

[11] Ferris V.R., Ferris J.M., Faghihi J., Variation in spacer ribosomal DNA in some cyst-forming species of plant parasitic nematodes, Fundam. Appl. Nematol. 16 (1993) 177-184.

[12] Futai K., Furuno T., The variety of resistances among pine-species to pinewood nematode, Bursaphelenchus lignicolus, Bull. Kyoto Univ. For. 51 (1979) 23-26.

[13] Hoyer U., Burgermeister W., Braasch H., Identification of Bursaphelenchus species (Nematoda: Aphelenchoididae) on the basis of amplified ribosomal DNA (ITS-RFLP), Nachrichtenbl. Deut. Pflanzenschutzd. 50 (1998) 273-277.

[14] Iwahori H., Tsuda K., Kanzaki N., Izui K., Futai K., PCR-RFLP and sequencing analysis of ribosomal DNA of Bursaphelenchus nematodes related to pine wilt disease, Fundam. Appl. Nematol. 21 (1998) 655-666.

[15] Jikumaru S., Togashi K., Inhibitory effect of Bursaphelenchus mucronatus (Nematoda: Aphelenchoididae) on B. xylophilus boarding adult Monochamus alternatus (Coleoptera: Cerambycidae), J. Nematol. 36 (2004) 95-99.

[16] Kolar C.S., Lodge D.M., Progress in invasion biology: predicting invaders, Trends Ecol. Evol. 16 (2001) 199-204.

[17] Liebhold A.M., MacDonald W.L., Bergdahl D., Mastro V.C., Invasion by exotic forest pest: A threat to forest ecosystems, For. Sci. Monogr. 30 (1995) 1-49.

[18] Linit M.J., Nematode-vector relationships in the pine wilt disease system, J. Nematol. 20 (1988) 227-235. 
[19] Maehara N., Futai K., Effect of fungal interactions on the numbers of the pinewood nematode, Bursaphelenchus xylophilus (Nematoda: Aphelenchoididae), carried by the Japanese pine sawyer, Monochamus alternatus (Coleoptera: Cerambycidae), Fundam. Appl. Nematol. 20 (1997) 611-617.

[20] Maehara N., Hata K., Futai K., Effect of blue-stain fungi on the number of Bursaphelenchus xylophilus (Nematoda: Aphelenchoididae) carried by Monochamus alternatus (Coleoptera: Cerambycidae), Nematology 7 (2005) 161-167.

[21] Mamiya Y., The pine wood nematode, in: Nickle W.R. (Ed.), Plant and insect nematodes, New York, USA, 1984, pp. 589-626.

[22] Mamiya Y., Origin of the pine wood nematode and its distribution outside the United States, in: Wingfield M.J. (Ed.), Pathogenecity of the pine wood nematode American Phytopathological Society Press, Saint Paul, Minnesota, USA, 1987, pp. 59-65.

[23] Mamiya Y., Enda N., Bursaphelenchus mucronatus n. sp. (Nematoda: Aphelenchoididae) from pine wood and its biology and pathogenicity to pine trees, Nematologica 25 (1979) 353-361.

[24] Mamiya Y., Kiyohara T., Description of Bursaphelenchus lignicolus n. sp. (Nematoda: Aphelenchoididae) from pine wood and histopathology of nematode-infested trees, Nematologica 18 (1972) 120-124.

[25] Mota M.M., Braasch H., Bravo M.A., Penas A.C., Burgermeister W., Metge K., Sousa E., First report of Bursaphelenchus xylophilus in Portugal and in Europe, Nematology 1 (1999) 727-734.

[26] Nickle W.R., A taxonomic review of the genera of the Aphelenchoidea (Fuchs 1937) Thorne 1949 (Nematoda: Tylenchida), J. Nematol. 2 (1970) 375-392.

[27] Penas A.C., Dias L.C., Mota M.M., Precision and selection of extraction methods of Aphelenchid nematodes from maritime pine woods, Pinus pinaster L., J. Nematol. 34 (2002) 62-65.

[28] Petney T.N., Andrews R.H., Multiparasite communities in animals and humans: frequency, structure and pathogenic significance, Int. J. Parasitol. 28 (1998) 377-393.

[29] Polomski J., Schönfeld U., Braasch H., Dobbertin M., Burgermeister W., Rigling D. Occurrence of Bursaphelenchus species in declining Pinus sylvestris in a dry Alpine valley in Switzerland, For. Pathol. 36 (2006) 110-118.

[30] Riga E., Beckenbach K., Webster J.M., Taxonomic relationships of Bursaphelenchus xylophilus and B. mucronatus based on interspecific and intraspecific cross hybridization, Fundam. Appl. Nematol. 15 (1992) 391-395.

[31] Riga E., Webster J.M., Use the sex pheromones in the taxonomic differentiation of Bursaphelenchus spp. (Nematoda), pathogens of pine trees, Nematologica 38 (1992) 133-145.
[32] Rühm W., Ein Beitrag zur Nomenklatur und Systematik einiger mit Scolytiden vergesellschafteter Nematodenarten, Zool. Anz. 164 (1960) 201-213.

[33] Ryss A., Vieira P., Mota M., Kulinich O., A synopsis of the genus Bursaphelenchus Fuchs, 1937 (Aphelenchida: Parasitaphelenchidae) with keys to species, Nematology 7 (2005) 393-458.

[34] Schauer-Blume M., Preliminary investigations on pathogenicity of European Bursaphelenchus species in comparison to Bursaphelenchus xylophilus from Japan, Rev. Nématol. 13 (1990) 191-195.

[35] Seinhorst J.W., A rapid method for the transfer of nematodes from fixative to anhydrous glycerin, Nematologica 4 (1959) 67-69.

[36] Shibata E., Okuda K., Transmission of the pine wood nematode, Bursaphelenchus xylophilus (Steiner and Buhrer) Nickle (Nematoda: Aphelenchoididae), by the Japanese pine sawyer, Monochamus alternatus Hope (Coleoptera: Cerambycidae), to pine twigs under laboratory conditions, Jpn. J. Nematol. 18 (1989) 6-14.

[37] Skarmoutsos G., Braasch H., Michalopoulos H., Bursaphelenchus hellenicus sp. n. (Nematoda, Aphelenchoididae) from Greek pine wood, Nematologica 44 (1998) 623-629.

[38] Sousa E., Naves P., Bonifácio L., Penas A.C., Pires J., Serrão M., Preliminary survey for insects associated with Bursaphelenchus xylophilus in Portugal, Bull. OEPP 32 (2002) 499-502.

[39] Steiner G., Buhrer E.M., Aphelenchoides xylophilus, n. sp. A nematode associated with blue-stain and other fungi in timber, J. Agric. Res. 48 (1934) 949-951.

[40] Togashi K., Transmission curves of Bursaphelenchus xylophilus (Nematoda: Aphelenchoididae) from its vector, Monochamus alternatus (Coleoptera: Cerambycidae), to pine trees with reference to population performance, Appl. Entomol. Zool. 20 (1985) 246-251.

[41] Tokushige Y., Kiyohara T., Bursaphelenchus sp. in the wood of dead pine trees (Japanese), J. Jpn. For. Soc. 51 (1969) 193-195.

[42] Vitousek P., Mooney H.A., Human domination of Earth's ecosystems, Science 277 (1997) 494-499.

[43] Vrain T.C., Restriction fragment length polymorphism separates species of the Xiphinema americanum group, J. Nematol. 25 (1993) 361-364.

[44] Yin K., Fang Y., Tarjan A.C., A key to species in the genus Bursaphelenchus with a description of Bursaphelenchus hunanensis sp. n. (Nematoda: Aphelenchoididae) found in pine wood in Hunan province, China, Proceedings of the Helminthological Society of Washington 55 (1988) 1-11. 